\title{
Microspinosporites, a new genus of Palaeozoic pseudosaccate miospores of flemingitalean affinity
}

\author{
JIŘÍ BEK
}

\begin{abstract}
Pennsylvanian microspinate/spinate mio- and microspores are formerly assigned to cingulate species of Lycospora (Schopf et al.), which were described by Potonié \& Kremp. In the present paper, from the three existing species of distally microspinate miospores of this type [L. granulata Kosanke, L. orbicula (Potonié \& Kremp) Smith \& Butterworth and L. chaloneri Scott \& Hemsley] two of them, L. orbicula and L. chaloneri are assigned to new pseudosaccate miospore genus Microspinosporites gen. nov. Miospores of this genus are characterized by inner body and distal and proximal microspinae/spinae, except for the contact area. A cingulum is not developed. The fructifications that produced Microspinosporites were bisporangiate cones of the genera Flemingites Carruthers and probably Moscvostrobus Naugolnykh \& Orlova, and were born on arborescent lycopsids of the genus Paralycopodites (Moorey \& Moorey) DiMichele. The morphology of Microspinosporites is similar to that of e.g., Geminospora (Balme) Playford and some other pseudosaccate miospore genera. $•$ Key words: Microspinosporites, Lycospora, Flemingites, Pennsylvanian, Carboniferous.
\end{abstract}

BEK, J. 2013. Microspinosporites, a new genus of Palaeozoic pseudosaccate miospores of flemingitalean affinity. Bulletin of Geosciences 88(3), 573-581 (1 figure, 1 table). Czech Geological Survey, Prague. ISSN 1214-1119. Manuscript received May 3, 2012; accepted in revised form September 4, 2012; published online June 12, 2013; issued July 3, 2013.

Jiři Bek, Institute of Geology, Academy of Sciences, v.v.i., Rozvojová 269, 16500 Prague 6, Czech Republic; mrbean@gli.cas.cz.

The miospore genus Lycospora (Schopf et al.) Potonié \& Kremp is one of the most abundant and most often recorded Carboniferous miospore genera (e.g. Smith 1962, Smith \& Butterworth 1967, Somers et al. 1972, Bek 2012). The genus was established by Schopf et al. (1944) and emended by Potonié \& Kremp (1954) and Somers et al. (1972). The first records of Lycospora concern its in situ occurrences from mono- and bisporangiate cones of the Lepidostrobus and Flemingites-types (Hooker 1848, Carruthers 1865 , Schimper 1870). Also the stratigraphically oldest records of Lycospora from the Upper Devonian of China are in situ from cones of arborescent lycopsids (Wang et al. 2003a, b). The stratigraphically youngest occurrences of Lycospora are from Permian strata both as in situ (Rayner 1986) and dispersed spores (Brugman et al. 1985, Gao 1985, Górecka \& Górecka-Nowak 1999, Lucas et al. 2006). The second emendation of the genus published by Somers et al. (1972) is important because several species were excluded from the genus. Many holotypes of $L y$ cospora species were described, figured and synonymised to four main species, Lycospora pusilla (Ibrahim) Potonié \& Kremp, L. noctuina Butterworth \& Williams, L. orbicula (Potonié \& Kremp) Smith \& Butterworth and L. rotunda Bharadwaj. The latest research of in situ Lycospora had been published especially from the Pennsylvanian of the Czech Republic (Bek \& Opluštil 1998, 2004, 2006; Opluštil \& Bek 2009). Criteria for a new division of Lycospora were suggested by Bek (2012) who divided Lycospora into six morphological groups, reporting seventy-one in situ records of Lycospora, proposed twenty-nine valid species and excluded sixty-three species from the genus. The main aim of this paper is the separation of one group of non-cingulate pseudosaccate miospores with densely microspinate/spinate sculpture on the distal and proximal surfaces (except for contact area), which were produced by bisporangiate cones of the Flemingites-type.

\section{Material and methods}

Spores are classified according to the system of dispersed spores suggested by Potonié \& Kremp $(1954,1955)$ and improved by Dettmann (1963) and Smith \& Butterworth (1967). The terms used for the description of the morphology, including the sculptural elements follows the classification of Punt et al. (2007). The species determinations are based only on these original diagnoses, and not on the interpretations of subsequent authors. In situ microspores 
macerated by the author and isolated from cones of the genus Flemingites Carruthers are stored in the Geological Institute, Academy of Sciences, v.v.i., Prague, Czech Republic. Dispersed miospores macerated by J. Drábková from the Ovčín locality, Radnice Basin, Czech Republic are stored in the Czech Geological Survey, Prague, Czech Republic.

A NIKON Eclipse 80i microscope was used for the study of the spores. In situ spores were recovered by dissolving small portions (separated from the cone specimens with a mounted needle) of cones in nitric acid (40 per cent) for 24-48 hours and $\mathrm{KOH}$ ( 5 per cent) for 20 minutes. Most spores were mounted in glycerine jelly for direct microscopic examination. Some spores were sputter-coated with gold for examination with a Cameca SX100 SEM. Dispersed miospores were macerated using nitric acid (40 per cent) for 12-24 hours and neutralised by $\mathrm{KOH}$ ( 5 per cent) for 10 minutes. The specimen with cones of Flemingites lycopoditis Feistmantel (No. 3536) from the Krčelák locality, Lubná, Rako Mine, Kladno-Rakovník Basin (Bolsovian) is stored in the National Museum, Prague, Czech Republic.

\section{Systematic position of cingulate Lycospora}

Lycospora miospores have been described as having equatorial structure usually named as a flange. Some palynologists interpreted this term as cingulum, some others as cingulum and zona. Morphological heterogeneity of the genus was recognised by Bharadwaj (1957) and Piérart (1964) who distinguished four types of Lycospora, Rotunda, Bizonaria and Microcingulata for cingulizonate and Lycospora for cingulate species. Smith \& Butterworth (1967, pp. 245-247) recognised two morphological types of $L y$ cospora, L. pusilla and L. pellucida (Wicher) Schopf et al., based on histograms of ratios of cingulum (and zona) width to spore radius. Also Thomas (1970), Thomas \& Dytko (1980) and Brack-Hanes \& Thomas (1983) recognised two main morphologically different types of Lycospora, cingulate and cingulizonate based on studies of in situ spores.

Bek (2012) recognised two groups of cingulate and four groups of cingulizonate Lycospora species. Cingulate Lycospora species were divided into morphologically different types that were produced by different parent cone and plant species (Bek \& Opluštil 2004, Opluštil \& Bek 2009, Bek 2012). The first type (Lycospora micropapillata Group) is represented by miospores with a microgranulate to microverrucate sculpture of both surfaces with a higher number of elements on the distal surface. Dispersed species of this group, Lycospora parva Kosanke, L. rugosa Schemel, L. tripapillata Ravn, L. micropapillata, L. pusilla, L. rugulosa Butterworth \& Spinner and L. granianellatus Staplin were usually produced by the longest and most robust monosporangiate cones of Lepidostrobus Brongniart, which could be more than one meter long and about twenty centimeters wide (Bek \& Opluštil 2004, Bek 2012). The second morphological type of cingulate Lycospora (Lycospora granulata Group) is different, because this group is typical for its densely microspinate/spinate distal surface and laevigate, or sometimes microgranulate/microverrucate proximal surface. Only three dispersed species, L. granulata Kosanke, L. orbicula and L. chaloneri Scott \& Hemsley were attributed to this group by Bek (2012). Miospores of the Lycospora micropapillata Group were produced by monosporangiate cones of the Lepidostrobus-type born on arborescent lycopsids of genera Lepidodendron Sternberg and Lepidophloios Sternberg, but spores of the Lycospora granulata Group were produced by bisporangiate Flemingites cones which belong to the arborescent lycopsid genus Paralycopodites (Morey \& Morey) DiMichele.

Morphological differences and different parent cones and plants are the reason for erection of a new miospore genus Microspinosporites gen. nov. for pseudosaccate, distally and proximally (except for laevigate contact area) microspinate miospores produced by the cone genera Flemingites and probably Moscvostrobus Naugolnykh \& Orlova (Bek 2012). Another morphological difference is the separation of an inner body, i.e. pseudosaccate character. Such a separation is not developed in all other species of Lycospora.

\section{Dispersed microspinate Lycospora}

The firstly erected dispersed species of this type, Lycospora granulata was established by Kosanke (1950, p. 45) for miospores with coarsely granulate exine and a small equatorial ridge. The diagnosis is poor (e.g. with no recognition of the sculpture of proximal and distal surfaces) and without mentioning the character and dimension of the equatorial structure. The holotype (Kosanke 1950, pl. 10, fig. 6) possesses a dark undulate ring delimiting the proximal surface. From the diagnosis, description and illustration is not clear if this structure is a cingulum or a prominent curvaturae, although it resembles a cingulum-like structure.

The second species of this group, Lycospora orbicula is described with (emendation given by Smith \& Butterworth 1967, p. 249) an indistinct very narrow cingulum that is less than $1 \mu \mathrm{m}$ in width and less than one-tenth of the radius. L. orbicula is not a typical species of the genus in that the cingulum is weakly developed. Potonié \& Kremp (1955, p. 63, pl. 13, fig. 179) and Smith \& Butterworth (1967, p. 249) defined L. orbicula for miospores with a denticulate margin, a finely granulate exine, and ornament lacking or reduced on the proximal surface. It is important, 
that in the diagnosis the cingulum is stated to be indistinct, very narrow and less than $1 \mu \mathrm{m}$ in width. In the description of L. orbicula, Smith \& Butterworth (1967, p. 249) described the cingulum as apparent only in slightly oblique compression and mentioned the occurrence of curvaturae. In fact, it is questionable if a cingulum can be less than $1 \mu \mathrm{m}$ wide because the width of the cingulum is usually more than $2 \mu \mathrm{m}$ (see Felix 1954; Willard 1989a, b; Bek \& Opluštil 2004, 2006; Bek 2012). Microspinae are less than $1 \mu \mathrm{m}$ long being of the same dimension as the equatorial structure.

The last dispersed species of this group, L. chaloneri, is known only in situ from cones Flemingites scottii (Jongmans) Brack-Hanes \& Thomas. This species possesses an equatorial structure 2-4 $\mu$ m wide. Scott \& Hemsley (1993, p. 37) interpreted this structure as cingulum and zona. Specimens illustrated by Scott \& Hemsley (1993, text-fig. 5B-G) and Hemsley et al. (1996, fig. 6; Fig. 10 herein) showing a prominent laevigate proximal contact area and microspinate/spinate remaining proximal portion and distal surface. It is important to realise that the proximal surface is sculptured except for contact area. We do not know any specimen of Lycospora with positive sculpture of cingulum or zona (Somers et al. 1972; Coquel 1972; Courvoisier \& Phillips 1975; Brack-Hanes \& Thomas 1983; Thomas 1988; Willard 1989a, b; Bek \& Opluštil 1998, 2004, 2006; Bek 2012). Also the prominent microspinae/spinae (or other positive sculpture elements) visible on the margin of spores are not seen on the margins of other Lycospora species. The photomicrographs in light microscopy of Scott \& Hemsley (1993, text-fig. 5C-F) are important in showing a narrow dark inner ring represented curvaturae, followed by narrow light middle ring and very narrow outer dark ring consists of microspinae/spinae. The contact area does not cover the whole proximal surface and no cingulum is seen. Hemsley et al. (1996, fig. 6; Fig. 10 herein) illustrated (SEM) the proximal surface of an in situ specimen of L. chaloneri where it is possible to see the sculptureless contact area, a sculptureless narrow inner ring (seen as a light middle ring using light microscopy) and a prominent outer ring of microspinae (seen as a dark sculptured outer ring on the margin).

Smith \& Butterworth (1967) illustrated dispersed L. orbicula with prominent inner body (Smith \& Butterworth 1967, pl. 20, fig. 19) and without cingulum (Smith \& Butterworth 1967, pl. 20, figs 16-18). Ravn (1986, pl. 18, figs 3, 4; Fig. 1D herein) illustrated dispersed L. orbicula with a microspinate margin and a prominent inner body. A cingulum, however, is not seen. Lycospora granulata published by Ravn (1986, pl. 18, figs 12-14) probably has a cingulum. It seems, that these miospores have microgranulate proximal surfaces. The specimen on Ravn's (1986) pl. 18, fig. 13 shows a relatively wide equatorial structure.

\section{In situ microspinate Lycospora}

Lycospora-producing cones have been referred to the genera Lepidostrobus and Flemingites (Balme 1995). Some Lepidostrobus cones were mono-, some others bisporangiate. Brack-Hanes \& Thomas (1983) studied the holotype of the type species, Lepidostrobus ornatus Brongniart, which yielded only cingulizonate Lycospora microspores. Therefore, the genus Lepidostrobus was re-defined for microsporangiate cones with cingulizonate and some of cingulate Lycospora microspores. Bisporangiate cones producing Lagenicula/Lagenoisporites megaspores and microspinate cingulate Lycospora microspores were assigned to the genus Flemingites by Brack-Hanes \& Thomas (1983).

Hoskins \& Cross (1940) mentioned the occurrence of microspores from bisporangiate cones of Lepidostrobus aristatus Hoskins \& Cross and Flemingites bartletii (Arnold) Brack-Hanes \& Thomas, but due to poor drawings (Hoskins \& Cross 1940, H, C, figs 15-18) it is not possible to be sure about the precise classification of these microspores.

Moore (1946) described and illustrated microspores isolated from bisporangiate cones Lepidostrobus comosus Lindley \& Hutton and $L$. cf. squarossus. The problem is, that Moore (1946) gave very poor descriptions and measurements of the spores, illustrated several hypothetic stages of maturity of microspores (combination of cingulate and cingulizonate forms with different sculptures) and therefore it is not possible to be sure about precise classification of these microspores.

Chaloner (1953) described microspores from bisporangiate cones Flemingites russelianus (Binney) Brack-Hanes \& Thomas, F. olryi (Zeiller) Brack-Hanes \& Thomas and F. dubius Binney (synonymous to Flemingites gracilis Carruthers). All of them are very similar and Chaloner (1953) mentioned that an equatorial structure is not present, or only very slightly. It is possible to see on Chaloner's illustrations (1953, text-figs 8, 17 and 23), that microspores of all the three cone species have prominent contact areas which only cover the majority of the proximal surface and that a cingulum is not developed.

Felix (1954) is probably the first, who published photomicrographs of in situ microspinate microspores of this type isolated from bisporangiate cones Flemingites diversus (Felix) Brack-Hanes \& Thomas and stressed their finely granulate (probably microspinate) sculpture. However the photomicrographs (Felix 1954, pl. 14, figs 14, 15; pl. 15 , fig. 16) are very poor and it is difficult to be sure about the precise classification of these microspores.

The study published by Balbach (1966) is important as she macerated in situ microspores from coal-balls specimens of $F$. diversus, described the occurrence of an inner body as an internal membrane and (Balbach 1966, p. 337) 
mentioned a ridge, that is not easily discernible and appears to be absent in about half of the spores. Very important is Balbach's (1966) remark, that a ridge is formed primarily by an extension of the distal wall with the proximal surface sloping down over it. It means, that the slightly darker ring in the equatorial region cannot be a cingulum (Fig. 1). Balbach (1966) was the first to show a lateral section of microspores of this type (Balbach 1966, pl. 2, fig. 4). It is possible to see an inner body and a different thickness of the distal and proximal exine (although Balbach did not give any measurements). It is also seen well, that there is no thickening/cingulum or zona in the equatorial region. The absence of the cingulum is also demonstrated by Balbach on pl. 2, fig. 2 (Fig. 1B herein), where the inner body is delimited by curvaturae. Microspores isolated by Balbach (1966) from Lepidostrobus sp. U also may correspond with those isolated from $F$. diversus, but there is not enough information to be sure about their precise classification.

Hagemann (1966) described distally microspinate microspores from a compression cone of Lepidostrobus sp. A with a prominent inner body (Hagemann 1966, taf. 1, figs 6, 8) and microspinate margin. Hagemann (1966, taf. 1, figs 14, 15) also showed a lateral view of compressed microspores where no equatorial thickening can be seen.

Permineralized bisporangiate cones of Flemingites schopfii (Brack) Brack-Hanes \& Thomas yielded distally rugulo-papillate microspores (Brack 1970). The arrangement of cone anatomy is identical with that of Lepidostrobus oldhamius Williamson except for the bisporangiate character. In contrast, a photomicrograph of Taylor et al. (2009) shows Lycospora with a sculptured proximal surface. Brack (1970) compared the in situ megaspores with the species Lagenicula rugosa (Loose) Arnold, but Taylor et al. (2009) assigned them to the morphologically different genus Valvisisporites (Ibrahim) Potonié \& Kremp, i.e. megaspores produced by sub-arborescent lycopsid genera Polysporia Newberry and Chaloneria Pigg \& Rothwell. Its identical anatomy with the monosporangiate (Courvoisier \& Phillips 1975, Willard 1989a) cone Lepidostrobus oldhamius is unusual as is the spore's sculptured proximal surface, because almost all other in situ microspores isolated from bisporangiate cones of the Flemingites-type possess a laevigate proximal hemisphere.

Courvoisier \& Phillips (1975) studied in situ microspores isolated from the permineralized cones Lepidostrobus oldhamius and Flemingites diversus. Microspores macerated from L. oldhamius are of two types. The first type (specimens 27, 35 and 42 in Courvoisier \& Phillips 1975, pl. 1, figs 1-15) possesses a wider equatorial structure, probably consisting of a cingulum and a zona (Courvoisier \& Phillips 1975, pl. 1, figs 3, 5, 9). Their distal surfaces are densely microspinate while their proximal surfaces are slightly microspinate (Courvoisier \& Phillips 1975, pl. 1, figs 4, 7, 8, 10) or nearly laevigate (Courvoisier
\& Phillips 1975, pl. 1, fig. 11). The second type of L. oldhamius microspores are different (specimens 38 and 113 in Courvoisier \& Phillips 1975, pl. 1, figs 12-17). Both surfaces are microspinate with lower number of sculpture elements on the proximal surface. No cingulum is seen on photomicrographs published by Courvoisier \& Phillips (1975). These microspores may resemble L. granulata, although Courvoisier \& Phillips (1975) assigned all L. oldhamius microspores to the dispersed miospore species Lycospora subjuga Bharadwaj, a typical cingulizonate species.

Microspores isolated (specimens 41 and 114 in Courvoisier \& Phillips 1975) from Flemingites diversus are without a cingulum as stated by Courvoisier \& Phillips (1975, p. 52). The equatorial structure is described as a false ridge. The distal surface is densely microspinate, the proximal surfaces are laevigate and the margins microspinate (Courvoisier \& Phillips 1975, pl. 2, fig. 8).

Brack-Hanes \& Thomas (1983) in their revision of genera Lepidostrobus and Flemingites mentioned in situ microspores from bisporangiate cone Flemingites gracilis, which are of the Microspinosporites-type.

Willard (1989a) named in situ microspores macerated from the permineralized cones Lepidostrobus oldhamius as Lycospora granulata. These cingulate microspores have granulate sculpture on both surfaces with a lower number of sculpture elements on the proximal hemisphere (Willard 1989a, figs 4, 7). The equatorial structure is unusualy wide (from 2.2 to $6.8 \mu \mathrm{m}$ ). Generally, they are similar to some in situ microspores isolated by Courvoisier \& Phillips (1975, specimens 27, 35 and 42) from some specimens of L. oldhamius.

Bek (1998) and Bek \& Opluštil (1998) described in situ microspores (Fig. 1G, L, N) of this type from bisporangite cones Flemingites lycopoditis and mentioned, that cingulum is hardly distinct". Opluštil \& Bek (2009) isolated microspores of the Lycospora orbicula-type from Flemingites cf. russelianus.

\section{Systematics}

Anteturma Sporites H. Potonié, 1893

Turma Triletes (Reinsch) Dettmann, 1963

Suprasubturma Pseudosaccitriletes Richardson, 1965

Infraturma Monopseudosacciti Smith \& Butterworth, 1967

\section{Genus Microspinosporites gen. nov.}

Type species. - Microspinosporites orbiculus (Potonié \& Kremp) comb. nov. emend.

Derivation of the name. - According to the typicallly densely microspinate sculpture of the distal and a part of the proximal surface. 
Table 1. Measurements of in situ and dispersed mio- and microspores of Microspinosporites gen. nov. and their stratigraphical ranges.

\begin{tabular}{|c|c|c|c|c|}
\hline \multicolumn{5}{|c|}{ Dispersed Microspinosporites } \\
\hline Dispersed species & Diameter $(\mu \mathrm{m})$ & Width of equatorial structure $(\mu \mathrm{m})$ & Stratigraphic level & f holotype \\
\hline Microspinosporites orbiculus & $26 \times 27$ & Not measured & Bolsovian & \\
\hline Microspinosporites chaloneri & $13.5-25.5$ & $2-4$ & Asbian & \\
\hline \multicolumn{5}{|c|}{ In situ Microspinoporites } \\
\hline Parent plant & Diameter $(\mu \mathrm{m})$ & Width of equatorial structure $(\mu \mathrm{m})$ & Stratigraphic level & Reference \\
\hline Lepidostrobus lycopoditis & $22-33$ & $2-2.2$ & Bolsovian & Bek (1998), Bek \& Opluštil (1998) \\
\hline Lepidostrobus diversus & $17-27$ & Not measured & Asturian & Balbach (1966) \\
\hline Lepidostrobus diversus & $19-26$ & 1.2 & Asturian & Felix (1954) \\
\hline Lepidostrobus diversus & $20-27$ & $1-1.5$ & Carbondale & Courvoisier \& Phillips (1975) \\
\hline Lepidostrobus oldhamius (in part) & $20-31$ & 1.5 & Carbondale & Courvoisier \& Phillips (1975) \\
\hline Flemingites dubius & $18-21$ & Not measured & Duckmantian & Chaloner (1953) \\
\hline Flemingites olryi & $19-34$ & Not measured & Duckmantian & Chaloner (1953) \\
\hline Flemingites russelianus & $20-34$ & Not measured & Duckmantian & Chaloner (1953) \\
\hline Lepidostrobus sp. A & $29-31$ & Not measured & Duckmantian & Hagemann (1966) \\
\hline Lepidostrobus bartletti & 20 & Not measured & & Felix (1954) \\
\hline Flemingites schopfii & $20-30$ & 2 & Langsettian & Brack (1970) \\
\hline Lepidostrobus sp. U & Not measured & Not measured & Asturian & Balbach (1966) \\
\hline Lepidostrobus comosus & $20-40$ & Not measured & Asbian & Moore (1946) \\
\hline Lepidostrobus cf. squarrosus & Not measured & Not measured & Asturian & Moore (1946) \\
\hline Moscvostrobus mirabile & $20-25$ & $2-4$ & Serpukhovian & Naugolnykh \& Orlova (2006) \\
\hline Flemingites gracilis & $18-21$ & $2-3$ & Duckmantian & Brack-Hanes \& Thomas (1983) \\
\hline Flemingites scotii & 20 & $2-4$ & Viséan & $\begin{array}{l}\text { Scott \& Hemsley (1993), } \\
\text { Hemsley et al. (1996) }\end{array}$ \\
\hline Lepidostrobus aristatus & $26-29$ & Not measured & Langsettian & Hoskins \& Cross (1940) \\
\hline Flemingites cf. russelianus & $26-37$ & $1-2$ & Westphalian & Opluštil \& Bek (2009) \\
\hline
\end{tabular}

Diagnosis. - Trilete pseudosaccate miospores. Circular to subcircular amb. Rays of trilete mark equal to the diameter of the inner body. The equatorial margin finely microspinate to spinate. Proximal surface microspinate to spinate except for laevigate contact area. Distal surface densely microspinate to spinate. Inner body laevigate. Exine is thicker on the distal than on the proximal hemisphere.

\section{Microspinosporites chaloneri (Scott \& Hemsley) comb. nov. emend.}

Figure $1 \mathrm{~B}, \mathrm{O}$

1993 Lycospora chaloneri Scott \& Hemsley, p. 37, text-fig. 5 .

Holotype. - BMNH V. 63848, Natural History Museum, London, UK.

Type locality. - Pettycur Fife, Scotland, UK.

Stratigraphic level. - Asbian.
Emended diagnosis. - Pseudosaccate trilete miospores, $13.5-25 \mu \mathrm{m}$ in diameter. Amb roundly triangular. Rays of trilete mark equal to the diameter of the inner body. Proximal surface microspinate and spinate except for laevigate contact area. Distal surface with spinae and microspinae. Microspinate outer part of the proximal surface $2-4 \mu \mathrm{m}$ wide.

\section{Microspinosporites orbiculus (Potonié \& Kremp) comb. nov. emend.}

Figure 1C-E, I, J, L, N

1955 Cyclogranisporites orbiculus Potonié \& Kremp, p. 63, pl. 13, figs 179-183.

1967 Lycospora orbicula (Potonié \& Kremp) Smith \& Butterworth, p. 249, pl. 20, figs 16-19.

Holotype. - Potonié \& Kremp, 1955, pl. 13, fig. 179. Preparation 607/2, KT 16.6110 .0 .

Type locality. - Baldur Seam, Brassert Colliery, Ruhr Coalfield, Germany. 


\section{Stratigraphic level. - Lower Bolsovian.}

Emended diagnosis. - Pseudosaccate trilete miospores, 20-35 $\mu \mathrm{m}$ in diameter. Amb circular to oval, margin microspinate. Laesurae simple, equal to the radius of the inner body, sometimes indistinct. Distal surface microspinate, proximal surface microspinate except for laevigate contact area. Distal exine thicker than exine of the proximal surface. Curvaturae sometimes developed. Contact area from three-quaters to the whole radius. Narrow folds commonly occur.

Remarks. - M. orbiculus is slightly larger (20-35 $\mu \mathrm{m})$ than M. chaloneri (13.5-25 $\mu \mathrm{m})$. Another difference is, that the contact area of $M$. chaloneri is more developed and more prominent. The sculpture elements of $M$. chaloneri are generally longer (microspinae and spinae) than those of M. orbiculus (only microspinae).

\section{Conclusions}

Microspinosporites belong to the group of pseudosaccate genera, especially with Grandispora (Hoffmeister et al.) McGregor, Geminospora (Balme) Playford, Leiozonotriletes Hacquebard, Spelaeotriletes Neves \& Owens. The suprasubturma Pseudosaccititriletes was proposed for: "Trilete spores with a well-developed cavity separating any two layers of the exine and which do not have, in addition, a solid flange. The exine may have a sculpture, infrastruc- ture or both." For discussion and comparison with similar taxa see Richardson (1965, pp. 584, 585).

The most similar are some species of the genera Leiozonotriletes, Geminospora and Grandispora. All these genera are characteristic by central body outline, which are not always distinct and are often not comformable with the equatorial outline which has a variable sculpture.

It seems that there are two types of microspinate/spinate and microgranulate mio- and microspores formerly assigned to the dispersed genus Lycospora, i.e. L. granulata, L. orbicula and L. chaloneri. Lycospora granulata probably possesses a narrow cingulum and the sculpture of proximal and distal surfaces is microgranulate and still represents the group of cingulate miospores sensu Bek (2012). Lycospora orbicula and L. chaloneri are pseudosaccate (Fig. 1A) with a densely microspinate/spinate distal surface, microspinate/spinate proximal surface except for the laevigate contact area and without cingulum. Both species are referred to the new genus Microspinosporites.

In situ microspores isolated from Lepidostrobus oldhamius (associated with Lepidophloios hallii Evers) by Willard (1989a) and Courvoisier \& Phillips (1975, in part) are cingulate with microspinate/microgranulate proximal and distal surfaces and probably correspond to the dispersed miospore species L. granulata.

In situ microspores isolated from bisporangiate cones F. diversus (Felix 1954, Courvoisier \& Phillips 1975), F. russelianus, F. olryi, F. dubius (Chaloner 1953), L. sp. A (Hagemann 1966), Flemingites schopfii (Brack 1970),

Figure 1. A - diagrammatic polar section of Geminospora lemurata Balme which corresponds to a section of the genus Microspinosporites gen. nov. Legend: pp - proximal pole; dp - distal pole; i - intexine; e - exoexine. From Playford (1983), fig. 5. • B - in situ Microspinosporites chaloneri (Scott \& Hemsley) comb. nov. emend. isolated from Flemingites scotii Jongmans. Notice the prominent inner body and the absence of a cingulum. From Balbach (1966), pl. 2, fig. 2. $\times 1000$. $・$ C - microspinate distal surface of dispersed Microspinosporites orbiculus (Potonié \& Kremp) comb. nov. emend. from the Ovčín locality, Radnice Basin, Czech Republic. $\times 1000$. D - proximal view of dispersed Microspinosporites orbiculus (Potonié \& Kremp) comb. nov. emend. Notice the inner body and the microspinate outer margin. From Ravn (1986), pl. 18, fig. 4. × 1000. • E - microspinate distal surface of Microspinosporites orbiculus (Potonié \& Kremp) comb. nov. emend. from the Ovčín locality, Radnice Basin, Czech Republic. SEM, $\times 2000$. - F - microspinate distal surface of Geminospora lemurata Balme. From Playford (1963), fig. 9B. SEM, $\times 1200$. • G - Microspinosporites orbiculus (Potonié \& Kremp) comb. nov. emend. in situ microspores isolated from Flemingites lycopoditis Feistmantel (No. 3536), Krčelák locality, Lubná, Rako Mine, Kladno-Rakovník Basin (Bolsovian). Notice the microspinate sculpture of the distal surface (right) and the sculpture of the proximal surface. The laevigate contact area makes about two-thirds of the radius, proximal surface (left) except for contact area is densely microspinate. SEM, $\times 2000$. - $\mathrm{H}$ - semi-lateral view on dispersed Geminospora lemurata Balme. Notice the laevigate proximal surface (left) and the densely microspinate part of the distal hemisphere (right). From Playford (1963), fig. 6C. SEM, $\times 1000$. • I - semi-lateral view of dispersed Microspinosporites orbiculus (Potonié \& Kremp) comb. nov. emend. from the Ovčín locality, Radnice Basin, Czech Republic. Notice the laevigate proximal surface (left) and the densely microspinate part of the distal hemisphere (right). SEM, $\times 2000$. $・ \mathrm{~J}-$ semi-lateral view of dispersed Microspinosporites orbiculus (Potonié \& Kremp) comb. nov. emend. from the Ovčín locality, Radnice Basin, Czech Republic. Notice the laevigate proximal surface (upper) and the densely microspinate part of the distal hemisphere (lower). SEM, $\times 2000$. $\bullet \mathrm{K}-$ proximal surface on in situ Geminospora lemurata Balme, isolated from Bisporangiostrobus harissii Chitaley \& McGregor. Notice the laevigate proximal surface and the microspinate/spinate margin. SEM, $\times 1000$. $\bullet$ L - proximal view of in situ Microspinosporites orbiculus (Potonié \& Kremp) comb. nov. emend. isolated from Flemingites lycopoditis Feistmantel (No. 3536), Krčelák locality, Lubná, Rako Mine, Kladno-Rakovník Basin (Bolsovian), × 2000. • M - semi-lateral view on dispersed Geminospora lemurata Balme. Notice the laevigate proximal surface and the densely microspinate part of the distal hemisphere. From Playford (1963), fig. 6F. SEM, $\times 1000$. $\bullet$ N - semi-lateral view of in situ Microspinosporites orbiculus (Potonié \& Kremp) comb. nov. emend. isolated from Flemingites lycopoditis Feistmantel (No. 3536), Krčelák locality, Lubná, Rako Mine, Kladno-Rakovník Basin (Bolsovian). Notice the laevigate proximal surface and the densely microspinate part of the distal hemisphere. SEM,$\times 2000$. $\bullet$ O - proximal surface of Microspinosporites chaloneri (Scott \& Hemsley) comb. nov. emend. Notice the laevigate contact area, which makes about three-quarters of the radius, the developed labrum and the microspinate part of the proximal surface. From Hemsley et al. (1993), fig. 6. SEM, $\times 2000$. 
Jiří Bek • Microspinosporites, a new genus of Palaeozoic pseudosaccate miospores
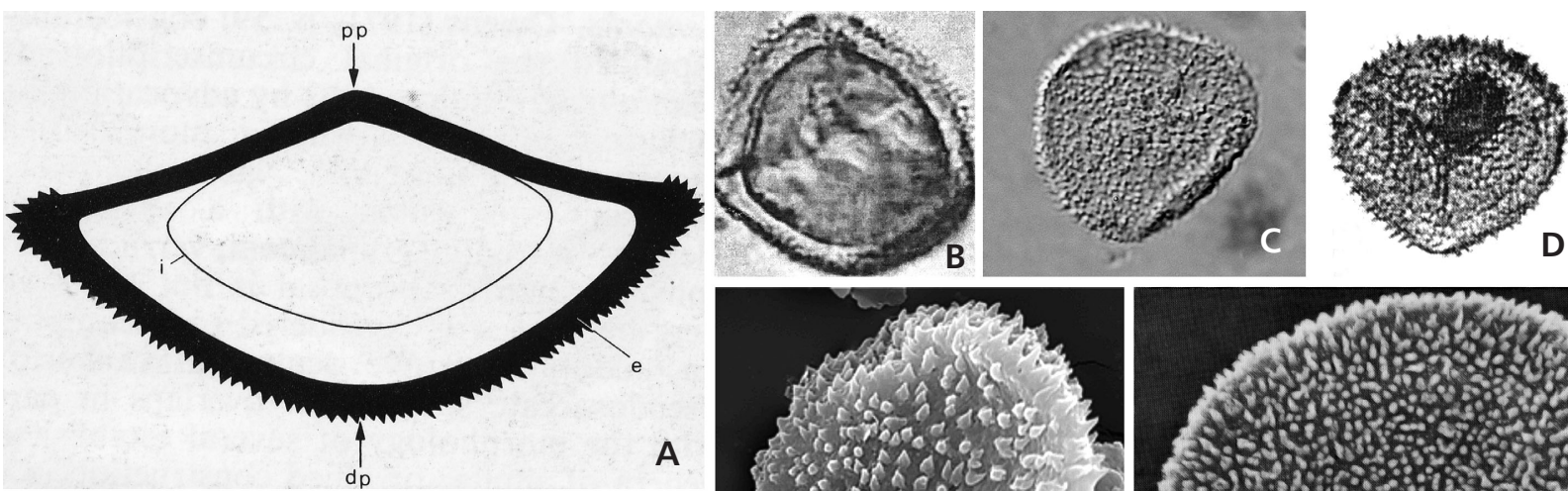

A
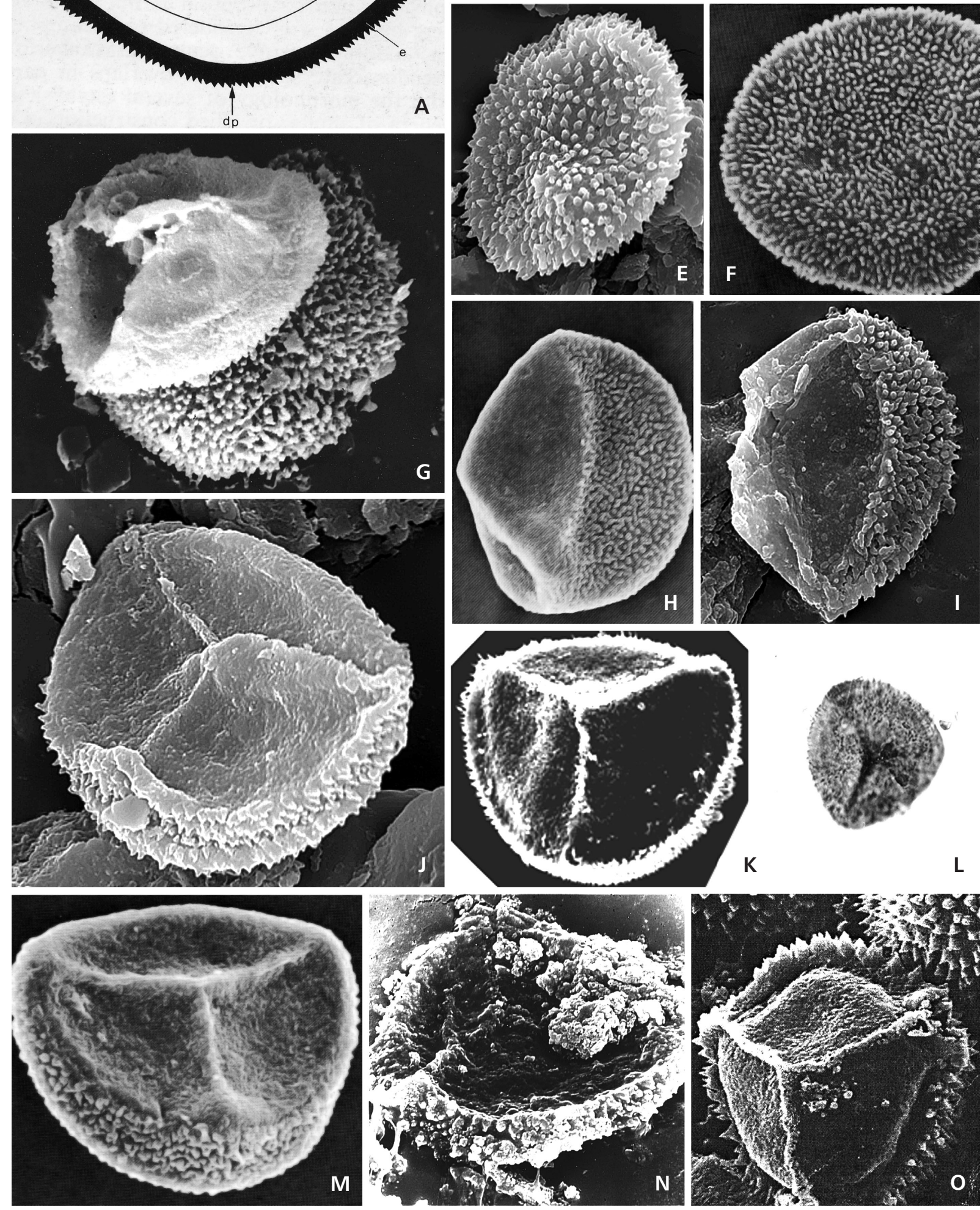
F. gracilis (Brack-Hanes \& Thomas 1983), F. lycopoditis (Bek \& Opluštil 1998) and F. cf. russelianus (Opluštil \& Bek 2009) are pseudosaccate, with microspinate distal and proximal surfaces except for the contact area and have no cingulum. All of them correspond to the new miospore genus Microspinosporites.

It seems, that some other pseudosaccate miospore genera, e.g. Geminospora, Grandispora and Leiozonotriletes have similar morphology to Microspinosporites. Playford (1983, pp. 312-316) in emendation of generic diagnosis of Geminospora mentioned the occurrence of curvaturae, a contact area occupying most or the whole proximal surface. The same type of sculpture elements on the distal surface and the same sculpture on the proximal surface is developed and the inner body can occupy 60 to 98 per cent of spore cavity. Geminospora usually possesses a thicker exine and a larger diameter. Specimens of Geminospora show a more prominent dark ring on the margin due to the thickness of exine (from 1.5 to $7 \mu \mathrm{m}$ ), which may resemble a cingulum (e.g. Chitaley \& McGregor 1989, pl. 10, figs 7-12), but, in fact, this represented a prominent curvaturae delimitating the contact area. SEM photomicrographs of dispersed (e.g. Playford 1983, figs 6-9; Fig. 1F, H, M) and in situ Geminospora (Chitaley \& McGregor 1989, Fig. 1K herein) are morphologically very similar (sometimes even identical) to mio- and microspores of Microspinosporites. Distal surfaces of both genera (Fig. 1E, F) are the same, lateral views (Fig. 1H, I) are closely similar as well as proximal sculptures (Fig. 1G, J, $\mathrm{K}, \mathrm{M}-\mathrm{O}$ ).

Microspinosporites-producing cones belong to the bisporangiate genera Flemingites and probably Moscvostrobus, born on arborescent lycopsids of the Paralycopodites-type.

\section{Acknowledgement}

I acknowledge financial support from the Grant Agency of the Academy of Sciences of the Czech Republic (P210/12/2053), the Research Program of the Institute of Geology AS CR, v.v.i. (AVOZ30130516, RVO67985831). I am very much obliged to Barry A. Thomas from the University of Aberysthwyth, UK for linguistic revision and several helpful comments and suggestions.

\section{References}

BALBACH, M.K. 1966. Microspore variation in Lepidostrobus and comparison with Lycospora. Micropaleontology 12, 334-342. DOI $10.2307 / 1484551$

BALme, B.A. 1995. Fossil in situ spores and pollen grains: an annotated catalogue. Review of Palaeobotany and Palynology 87, 81-323. DOI 10.1016/0034-6667(95)93235-X

BeK, J. 2012. A review of the genus Lycospora. Review of
Palaeobotany and Palynology 174, 122-135.

DOI 10.1016/j.revpalbo.2011.12.008

BeK, J. \& Opluštil, S. 1998. Some lycopsid, sphenopsid and pteropsid fructifications and their miospores from the Upper Carboniferous basins of the Bohemian Massif. Palaeontographica, Abteilung B 248, 127-161.

BeK, J. \& OpluštiL, S. 2004. Palaeoecological constraints of some Lepidostrobus cones and their parent plants from the Late Palaeozoic continental basins of the Czech Republic. Review of Palaeobotany and Palynology 131, 49-89.

DOI 10.1016/j.revpalbo.2004.02.008

BeK, J. \& OpluštiL, S. 2006. Six rare Lepidostrobus species from the Pennsylvanian of the Czech Republic and their bearing on the classification of lycospores. Review of Palaeobotany and Palynology 139, 211-226.

DOI 10.1016/j.revpalbo.2006.01.003

BHARADWAJ, D.C. 1957. The palynological investigations of the Saar coals. Palaeontographica, Abteilung B 101, 73-125.

Brack, S.D. 1970. On a lycopsid cone with winged spores. Botanical Gazzette 142(2), 294-304. DOI 10.1086/337226

Brack-Hanes, S.D. \& Thomas, B.A. 1983. A re-examination of Lepidostrobus Brongniart. Botanical Journal of Linnaean Society 86, 125-133. DOI 10.1111/j.1095-8339.1983.tb00720.x

Brugman, W.A., Eggink, J.W., Loboziak, S. \& Visscher, H. 1985. Late Carboniferous-Early Permian (GhzelianArtinskian) palynomorphs. Journal of Micropalaeontology 4, 93-106. DOI 10.1144/jm.4.1.93

CARruthers, W. 1865. On Caulopteris punctata, Goepp., a tree fern from the Upper Greensand of Shaftesbury in Dorsetshire. Geological Magazine 2, 484.

DOI 10.1017/S0016756800162351

Chaloner, W.G. 1953. On the megaspores of four species of Lepidostrobus. Annales of Magazine of Natural History 17, 66, 263-293.

Chitaley, S. \& McGregor, C. 1989. Bisporangiostrobus harrissii gen. et sp. nov., an eligulate lycopsid cone with Duosporites megaspores and Geminospora microspores from the Upper Devonian of Pennsylvanian, U.S.A. Palaeontographica B 210, 127-149.

Courvoisier, J.M. \& Phillips, T.L. 1975. Correlation of spores from Pennsylvanian coal-ball fructifications with dispersed spores. Micropaleontology 21, 45-49. DOI 10.2307/1485154

CoQuel, R. 1972. Etude au microscope électronique à balayage de l'ornamentation de Lycospora pusilla (Ibrahim) Somers, spore trilète du Carbonifère. Annales de Sociéte Géologiques de la Nord 93, 237-240.

Dettmann, M.E. 1963. Upper Mesozoic microfloras from southeastern Australia. Proceedings of Royal Society of Victoria 77, $1-148$.

Felix, C.J. 1954. Some American arborescent lycopod fructifications. Annales of Missourian Botanical Garden 41, 351-394. DOI 10.2307/2394684

GAO, L. 1985. Carboniferous and Early Permian spore assemblages of North China region and the boundary of the Carboniferous and Permian. $10^{\text {th }}$ Congress of International Stratigraphy, Geology of Carboniferous, Madrid 1983, Compte Rendu 2, 409-424.

GóReCKA, T. \& GóReCKA-NowAK, A. 1999. Palynostratigraphic studies of Upper Carboniferous deposits from the Intra- 
Sudetic Basin, Southwestern Poland. Review of Palaeobotany and Palynology 6, 287-292.

Hagemann, H.W. 1966. Sporen aus köhligerhaltenen Lepidophytenzapfen des Westfals. Fortschritte in der Geologie von Rheinland und Westphalen 13(1), 317-388.

Hemsley, A.R., Scott, A.C., Barrie, P.J. \& Chaloner, W.G. 1996. Studies of fossil and modern spore wall biomacromolecules using C-13 solid state NMR. Annales of Botany 78, 83-94. DOI 10.1006/anbo.1996.0099

HOOKER, J.D. 1848. The vegetation of the Carboniferous period as compared with that of the present day. Memoirs of the Geological Survey of England and Wales 2, 387-430.

Hoskins, J.H. \& Cross, A.T. 1940. Two new species of Lepidostrobus from the Lower Pottsville of Orange County, Indiana. American Midland Naturalist 24(2), 421-436. DOI 10.2307/2420945

KosanKe, R.M. 1950. Pennsylvanian spores of Illinois and their use for correlation. Bulletin of Illinois State Geological Survey $74,1-128$.

Lucas, S.G., CAssini, G. \& Schneider, J.W. 2006. Non-marine Permian biostratigraphy and biochronology. Geological Society, Special Publications 265, 1-15. DOI 10.1144/GSL.SP.2006.265.01.01

Moore, L.R. 1946. On the spores of some Carboniferous plants, their development. Quartenarly Journal of Geological Society of London 102, 251-298. DOI 10.1144/GSL.JGS.1946.102.01-04.14

Naugolnykh, S.V. \& Orlova, O.A. 2006. Moscvostrobus, a new genus of Carboniferous lycopods from the Moscow region, Russia. The Palaeobotanist 55, 1-14.

Opluštil, S. \& BeK, J. 2009. Some Pennsylvanian arborescent lycopsid cones and their microspores from the British coalfields. Bulletin of Geosciences 84(2), 203-226. DOI 10.3140/bull.geosci.1081

PiÉRART, P. 1964. Lycospora Schopf, Wilson and Bentall. Fifth International Congress on Carboniferous stratigraphy and geology, Compte Rendu 3, 1059-1061.

Playford, G. 1983. The Devonian miospore genus Geminospora Balme 1962: a reappraisal based upon topotypic G. lemurata (type species). Memoirs of Association of Australian Palaeontologists 1, 311-325.

PotoniÉ, H. 1893. Die floristiche Gliederung des deutschen Carbon und Perm. Abhandlungen Kaiser und Preuss geologische Landesant, Neue Folge 21.

Potonié, R. \& Kremp, G. 1954. Die Gattungen der Palaözoischen Sporae dispersae und ihre Stratigraphie. Geologische Jahrbuch 69, 111-193.

Potonié, R. \& Kremp, G. 1955. Die Sporae dispersae des Ruhrkarbons ihre Morphographie und Stratigraphie mit Ausblicken auf Artenanderer Gebiete und Zeitabschnitte. Teil I. Palaeontographica B 98, 1-136.

Punt, W., Hoen, P.P., Blackmore, S., Nilsson, S. \& LeThomas, A. 2007. Glossary of pollen and spore terminology. Review of Palaeobotany and Palynology 143, 1-81. DOI 10.1016/j.revpalbo.2006.06.008

RAYNER, R.J. 1986. A new genus of lycopod from South Africa. Review of Palaeobotany and Palynology 47, 129-143. DOI 10.1016/0034-6667(86)90010-2
Ravn, R.L. 1986. Palynostratigraphy of the Lower and Middle Pennsylvanian coals of Iowa. Iowa Geological Survey, Technical Papers 7, 1-165.

Richardson, J.B. 1965. Middle Old Red Sandstone spore assemblages from the Orcadian Basin, north-east Scotland. Palaeontology 7, 559-605.

SCHIMPER, W.P. 1870. Traité de Paléontologie végétale, ou La flore du monde primitif dans ses rapports avec les formations géologiques de la flora du monde actuel. Vol. 2. Ballière, Paris.

Schopf, J.M., Wilson, L.R. \& Bentall, R. 1944. An annotated synopsis of Paleozoic fossil spores and the definition of generic groups. Reports of Investigations of Illinois Geological Survey 91, 1-66.

Scott, A.C. \& Hemsley, A.R. 1993. The spores of Dinantian lycopsid cone Flemingites scotii from Pettycur, Fife, Scotland. Special Papers in Palaeontology 49, 31-41.

SMith, A.H.V. 1962. The palaeoecology of Carboniferous peats based on the miospores and petrography of bituminous coals. Proceedings of Yorkshire Geological Society 33, 423-474. DOI 10.1144/pygs.33.4.423

Smith, A.H.V. \& Butterworth, M.A. 1967. Miospores in the coal seams of the Carboniferous of Great Britain. Special Papers in Palaentology 1, 1-324.

Somers, Y., Alpern, B., Doubinger, J. \& Grebe, H. 1972. Revision du genre Lycospora Schopf, Wilson \& Bentall, 9-10. In Alpern, B. \& StREel, M. (eds) Les Spores 5. Microfossiles organiques du Paléozoïque. Centre national de la Recherche scientifique (CNRS), Paris.

TAYlor, T.N., TAYlor, E.L. \& Krings, M. 2009. Paleobotany: The morphology and evolution of fossil plants. $1230 \mathrm{pp}$. Elsevier Academic Press, Burlington.

Thomas, B.A. 1970. A new specimen of Lepidostrobus binneyanus from the Westphalian B of Yorkshire. Pollen et Spores 12, 217-234.

Thомаs, B.A. \& Dyтко, A. 1980. Lepidostrobus haslingdenensis: A new species from the Lancashire Millstone Grit. Geological Journal 15, 137-142. DOI 10.1002/gj.3350150207

ThomAs, B.A. 1988. The fine structure of the Carboniferous lycophyte microspore Lycospora perforata Bharadwaj and Venkatachala. Pollen et Spores 30, 81-88.

WANG, Q.S., HAO, D., WANG, D. \& Dilcher, D.L. 2003a. An anatomically preserved arborescent lycopsid, Sublepidodendron songziense (Sublepidodendraceae), from the Late Devonian of Hubei, China. American Journal of Botany 89, 1468-1477. DOI 10.3732/ajb.89.9.1468

Wang, Q., Li, C., Geng, B. \& Chitaley, S. 2003b. A new species of Lepidostrobus from the Upper Devonian of Xinjiang, China and its bearing on the phylogenetic significance of the order Isoëtales. Botanical Journal of Linnaean Society 143, 55-67. DOI 10.1046/j.1095-8339.2003.00200.x

Willard, D.A. 1989a. Source plants for Carboniferous microspores: Lycospora from permineralized Lepidostrobus. American Journal of Botany 76, 820-826. DOI $10.2307 / 2444538$

WiLlard, D.A. 1989b. Lycospora from Carboniferous Lepidostrobus compressions. American Journal of Botany 76, 1429-1440. DOI 10.2307/2444429 